\title{
Kajian Distribusi Suhu dan Efisiensi Alat Pengering Pati Sagu Agitated Fluidized Bed Tipe Silinder Bertingkat Berbahan Bakar Kayu dan Tempurung Kelapa
}

\section{Study on the Temperature Distribution and Efficiency of the Agitated Fluidized Bed of Multy- Storey Cylindrical Type of Sago Starch Dryer Using Firewood and Coconut Shell}

\author{
Abadi Jading ${ }^{1 *}$, Wilson Palelingan Aman ${ }^{1}$, Bennydictus Fangohoy ${ }^{2}$ \\ ${ }^{1}$ Jurusan Teknik Pertanian dan Biosistem, Universitas Papua \\ J1. Gunung Salju amban, Manokwari 98314. \\ ${ }^{2}$ Jurusan Teknologi Hasil Pertanian, Universitas Papua \\ J1. Gunung Salju amban, Manokwari 98314. \\ *Email: a.jading@unipa.ac.id
}

\begin{abstract}
Sago starch drying with a multi-storey cylindrical agitated fluidized bed dryer has been carried out. The purpose of this study was to assess the temperature distribution and drying efficiency of the Agitated Fluidized Bed type cylindrical Agitated Bed (AFB Type PSB) using wood biomass fuel and coconut shell. To calculate the amount of energy and efficiency during the drying process, $a$ mathematical analysis was used. The temperature distribution that occurs in the agitator chamber is evenly distributed. The PSB type AFB dryer has a capacity of $30 \mathrm{~kg} / 5$ hours. The efficiency of drying and drying equipment for firewood is $38.09 \%$ and $2.5 \%$ respectively, while for coconut shells $37.76 \%$ and $2.1 \%$, with biomass energy consumption of $1072 \times 103 \mathrm{~kJ}$, coconut shell of $1274 \times 10^{3} \mathrm{~kJ}$, and electrical energy of $55.98 \times 10^{3} \mathrm{~kJ}$. The drying temperature in the agitator chamber $\left(50.64^{\circ} \mathrm{C}-54.82^{\circ} \mathrm{C}\right)$ and fluidization $\left(66.64^{\circ} \mathrm{C}\right)$ for firewood, while for coconut shell the temperature in the agitator chamber $\left(49.55^{\circ} \mathrm{C}-53.82^{\circ} \mathrm{C}\right)$ and fluidization chamber $\left(64.27^{\circ} \mathrm{C}\right)$. The PSB type AFB dryer was able to reduce the water content of sago starch from $42 \%$ wet basis to $12.02 \%$ for wood fuel, and $12.21 \%$ for coconut shell fuel.
\end{abstract}

Keywords: agitated fluidized bed, energy, efficiency, temperature

\begin{abstract}
Abstrak
Pengeringan pati sagu dengan pengering agitated fluidized bed tipe silinder bertingkat telah dilakukan. Tujuan penelitian ini adalah mengkaji distribusi suhu dan efisiensi pengering pati sagu model Agitated Fluidized Bed tipe Piringan-Silinder Bertingkat (AFB Tipe PSB) menggunakan bahan bakar biomassa kayu dan tempurung kelapa. Untuk menghitung besarnya energi dan efisiensi selama proses pengeringan, maka digunakan analisis matematis. Distribusi suhu yang terjadi di dalam ruang agitator merata dengan baik. Pengering AFB tipe PSB memiliki kapasitas $30 \mathrm{~kg} / 5 \mathrm{jam}$. Efisiensi pengeringan dan alat pengering untuk kayu bakar adalah $38,09 \%$ dan 2,5\%, sedangkan untuk tempurung kelapa $37,76 \%$ dan $2,1 \%$, dengan konsumsi energi biomassa kayu bakar $1072 \times 10^{3} \mathrm{~kJ}$, tempurung kelapa1274 $\mathrm{x} 10^{3} \mathrm{~kJ}$, energi listrik $55,98 \times 10^{3} \mathrm{~kJ}$. Suhu pengeringan dalam ruang agitator $\left(50,64^{\circ} \mathrm{C}-54,82^{\circ} \mathrm{C}\right)$ dan fluidisasi $\left(66,64^{\circ} \mathrm{C}\right)$ untuk kayu bakar, sedangkan untuk tempurung kelapa suhu dalam ruang agitator $\left(49,55^{\circ} \mathrm{C}-53,82^{\circ} \mathrm{C}\right)$ dan ruang fluidisasi $\left(64,27^{\circ} \mathrm{C}\right)$. Pengering AFB tipe PSB mampu menurunkan kadar air pati sagu dari $42 \%$ basis basah menjadi $12,02 \%$ untuk bahan bahan bakar kayu, dan $12,21 \%$ untuk bahan bakar tempurung kelapa.
\end{abstract}

Kata kunci: agitated fluidized bed, energi, efisiensi, suhu

\section{PENDAHULUAN}

Sagu merupakan tanaman asli Indonesia, tumbuh mendominasi di kawasan timur Indonesia. Di Indonesia sentra pertanaman sagu tersebar di Papua, Papua Barat, Maluku, Maluku Utara, Riau, Sulawesi, dan Kalimantan. Saat ini belum diketahui 
secara pasti luas lahan sagu dunia. Di Indonesia, informasi mengenai luas areal sagu menurut Bintoro (2019) sekitar 5.519.637 Ha (Papua 4.749.325 Ha, dan Papua Barat $510.213 \mathrm{Ha}$ ). Oleh karena itu, sagu dalam satu hektar dapat menghasilkan 20-40 ton pati, jika dijumlahkkan dengan luas areal sagu sebesar 5 juta Ha akan menghasilkan 100-200 juta ton.

Pati merupakan komponen kimia terbesar yang terdapat pada batang sagu. Pati sagu diperoleh dari proses ekstraksi inti batang (empulur) tanaman sagu. Menurut Flach (1983), empulur batang sagu mengandung 20,2-29\% pati, 50-66\% air dan 13,8-21,3\% bahan lain atau ampas. Dihitung dari berat kering, empulur batang sagu mengandung 54$60 \%$ pati dan $40-46 \%$ ampas. Untuk membebaskan granula pati dari jaringan pengikatnya dibutuhkan perombakan dinding sel dengan pemarutan atau penggilingan dengan menggunakan air sebagai pemisah antara padatan dengan pati.

Pati sagu dapat dikeringkan secara alami (penjemuran) tanpa alat pengering maupun menggunakan peralatan pengering buatan. Pengeringan merupakan suatu cara untuk mengeluarkan atau menghilangkan sebagian besar air dari suatu bahan dengan menggunakan energi panas. Pada saat pengeringan dimulai, uap panas yang dialirkan meliputi permukaan bahan akan menaikan tekanan uap air, terutama pada daerah permukaan, sejalan dengan kenaikan suhunya. Pada saat proses ini terjadi perpindahan air dari bahan ke udara dalam bentuk uap air berlangsung atau terjadi pengeringan pada permukaan bahan. Chung dan Chang (1982) menyatakan bahwa tujuan utama dari proses pengeringan adalah untuk mengurangi kandungan air dalam bahan sehingga dapat menghambat pertumbuhan mikroba maupun reaksi lainnya. Selain itu produk yang dikeringkan akan lebih mudah dalam pengangkutan dan penyimpanan.

Kemampuan bahan untuk menguapkan air akan bertambah cepat dengan adanya kenaikan suhu sedangkan panas yang diperlukan untuk menguapkan air akan berkurang dengan naiknya suhu pengeringan. Menurut Marsetio (2009) laju pengeringan dipengaruhi oleh faktor-faktor yang berhubungan dengan proses pengeringan tersebut. Beberapa faktor yang sukar diawasi adalah luas permukaan bahan, distribusi aliran udara, struktur molekular bahan dan distribusi suhu dalam tenun bahan. Faktor-faktor lain yang mempengaruhi laju pengeringan ialah tekanan uap air pada suhu pengeringan maksimum, tekanan luar udara dan uap air, kecepatan pindah panas ke permukaan bahan, tekanan uap keseimbangan dari dalam bahan dan kadar air bahan. Pada pengering buatan dibutuhkan suhu pengering yang berasal dari panas hasil pembakaran bahan bakar. Jenis bahan bahan bakar yang sering digunakan adalah biomassa, berupa kayu bakar dan tempurung kelapa. Kayu memiliki sekitar 50\% karbon, 44\% oksigen dan $6 \%$ hidrogen bila diukur pada kondisi bebas abu dan bebas kelembaban. Biasanya ada sekitar satu persen abu dalam kayu dan ini tidak jauh berbeda antara spesies satu dengan lainnya, karena kandungan karbon dan hidrogen pada kayu yang menentukan nilai panas intrinsiknya, maka satu kilogram dari setiap jenis kayu tanpa kandungan air akan mengandung kurang lebih jumlah panas yang sama (Manual Statistik Energi, 2005).

Nilai panas atau nilai kalor dari kayu akan banyak dipengaruhi oleh kandungan kelembapan dari kayu tersebut. Kayu hijau yang baru saja dipotong memiliki nilai panas sekitar 8,2 MJ/kg sedangkan kayu kering udara (kelembapan 10\% sampai 20\%) memiliki nilai panas sekitar $16 \mathrm{MJ} / \mathrm{kg}$. Kayu yang benarbenar kering (kering-oven) memiliki panas sekitar $18 \mathrm{MJ} / \mathrm{kg}$ (Manual Statistik Energi, 2005),

Tempurung kelapa merupakan bagian yang melapisi buah kelapa dan memiliki komposisi kimia mirip dengan kayu, mengandung lignin, pentosa, dan selulosa. Tempurung kelapa dalam penggunaan biasanya digunakan sebagai bahan pokok pembuatan arang dan arang aktif, hal tersebut dikarenakan tempurung kelapa merupakan bahan yang dapat menghasilkan nilai kalor sekitar 6500 - $7600 \mathrm{kkal} / \mathrm{kg}$. Selain memiliki nilai kalor yang cukup tinggi, tempurung kelapa juga cukup baik untuk bahan arang aktif (Suryani, 1986). Menurut Palungkun (1999) dalam Safrizal et al., (2012) nilai kalor tempurung kelapa adalah 18,20-19,30 MJ/kg.

Salah satu alat pengering pati sagu yang dikembangkan adalah alat pengering pati sagu model agitated fluidized bed. Kelebihan dari alat pengering ini adalah mampu mempercepat proses pengeringan dengan kualitas yang lebih baik dari pengeringan alami. Jading dkk. (2012) menyempurnakan alat tersebut dengan 
menambahkan pengaduk menjadi model Agitated Fluidized Bed tipe Piringan-Silinder Bertingkat (AFB Tipe PSB), sehingga diharapkan dapat lebih mempercepat proses pengeringan. Proses fluidisasi pada alat pengering AFB Tipe PSB dapat berlangsung dengan baik jika aliran udara yang melalui bahan tidak mengalami hambatan.

Kinerja pengering AFB dari hasil penambahan komponen pengadukan pada alat pengering tersebut telah dikaji oleh Jading dkk. (2015) dan Jading dkk. (2019). Namun demikian, distribusi suhu dan kebutuhan energi, serta efisiensi pengeringan belum diketahui pada alat pengering tersebut dalam proses pengeringan pati sagu. Tujuan penelitian ini adalah mengkaji distribusi suhu dan efisiensi pengering pati sagu model Agitated Fluidized Bed tipe Piringan-Silinder Bertingkat (AFB Tipe PSB) menggunakan bahan bakar biomassa kayu dan tempurung kelapa.

\section{METODOLOGI}

Bahan yang digunakan dalam penelitian adalah pati sagu basah yang diperoleh dari hasil pengolahan sagu rakyat di Wasior, kabupaten Teluk Wondama. Bahan lain yang digunakan adalah bahan bakar biomassa yaitu kayu bakar (kayu nangka) dan tempurung kelapa yang diperoleh dari masyarakat sekitar kabupaten Manokari. Peralatan yang digunakan terdiri dari pengering pati sagu AFB Tipe PSB, termometer digital dan thermokopel tipe-K untuk mengukur suhu, serta timbangan untuk mengukur bobot pati sagu dan bahan bakar. Pengering pati sagu AFB Tipe PSB terdiri dari ruang pengering berbentuk silinder secara bertingkat dengan 3 tingkatan, dan ruang fluidisasi. Adapun skema dan konstruksi pengering pati sagu AFB Tipe PSB dapat diihat pada Gambar 1 dan 2.

Penelitian ini adalah penelitian eksperimen melalui pengujian pengering AFB tipe PSB. Pengujian pengering pati sagu AFB tipe PSB dilakukan di laboratorium Teknologi Pertanian Fakultas Teknologi Pertanian (FATETA) Universitas Papua (UNIPA) Manokwari. Variabel perlakuan meliputi jenis bahan bakar biomassa, yaitu kayu bakar dan tempurung kelapa. Variabel pengamatan meliputi distribusi suhu, efisiensi pengeringan, dan efisiensi alat pengering AFB tipe PSB.
Tahapan pengujian pengering AFB tipe PSB meliputi persiapan bahan penelitian yaitu pati sagu dan bahan bakar biomassa (kayu bakar dan tempurung kelapa), pengukuran suhu dan kelembaban pada titiktitik pengukuran yang telah ditentukan pada bagian-bagian pengering AFB tipe PSB. Pati sagu mula-mula dicuci dan ditiriskan, untuk mengurangi jumlah air yang ada pada permukaan pati sagu. Pati sagu yang telah ditiriskan diambil sebagian untuk pengujian kadar air awal. Pengujian kadar air menggunakan metode oven atau gravimetri (AOAC, 2005).

Pati sagu basah sebagai sampel pengeringan ditimbang masing-masing sebanyak $30 \mathrm{~kg}$ pada setiap perlakuan bahan bakar (kayu bakar dan tempurung kelapa). Selanjutnya persiapan bahan bakar kayu bakar dan tempurung kelapa. Bahan bakar yang telah ditimbang kemudian dimasukkan ke dalam ruang pembakaran secara bertahap sampai proses pembakaran normal, selanjutnya blower dihidupkan untuk mendorong udara pengering dari ruang pindah panas ke dalam ruang pengering (silinder agitator bertingkat dan fluidisasi) hingga mencapai mencapai suhu $50^{\circ} \mathrm{C}$. Pada tahap ini pati sagu yang telah ditiriskan dan ditimbang $(30 \mathrm{~kg})$, dimasukan dalam ruang agitator melalui hopper, setelah itu tenaga penggerak agitator dihidupkan.

Pengukuran suhu saat pengujian, dilakukan menggunakan termometer digital dan display pengukur suhu pada pengering AFB tipe PSB, sesuai titik-titik pengukuran suhu $T_{1}, T_{2}, T_{3}$ pada silinder atas, pengukuran suhu $\left(\mathrm{T}_{4}, \mathrm{~T}_{5}, \mathrm{~T}_{6}\right)$ pada silinder tengah, pengukuran suhu $\left(T_{7}, T_{8}, T_{9}\right)$ pada silinder bawah, dan pengukuran suhu $\left(\mathrm{T}_{10}\right)$ pada ruang fluidisasi. 


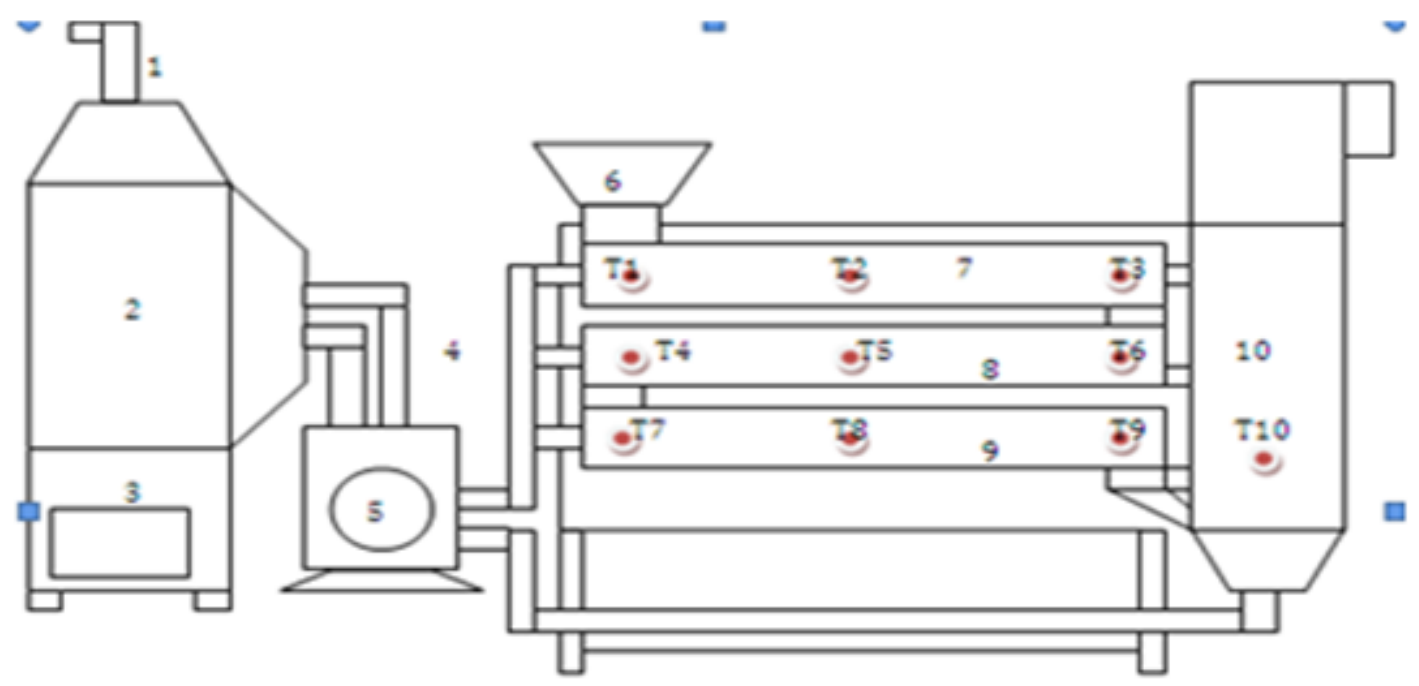

Ket: 1 . Cerobong tungku biomassa

2. Ruang pemindah panas tungku biomassa

3. Ruang pembakaran tungku biomassa

4. Pipa saluran udara pengering

5. Blower

\section{Hopper pengering}

7. Silinder agitator atas pengering

8. Silinder agitator tengah pengering

9. Silinder agitator bawah pengering

10. Ruang fluidisasi pengering

T1-T10 Titik pengukuran suhu pada silinder pengeringan

Gambar 1. Skema pengering pati sagu agitated fluidized bed tipe piringan silinder bertingkat
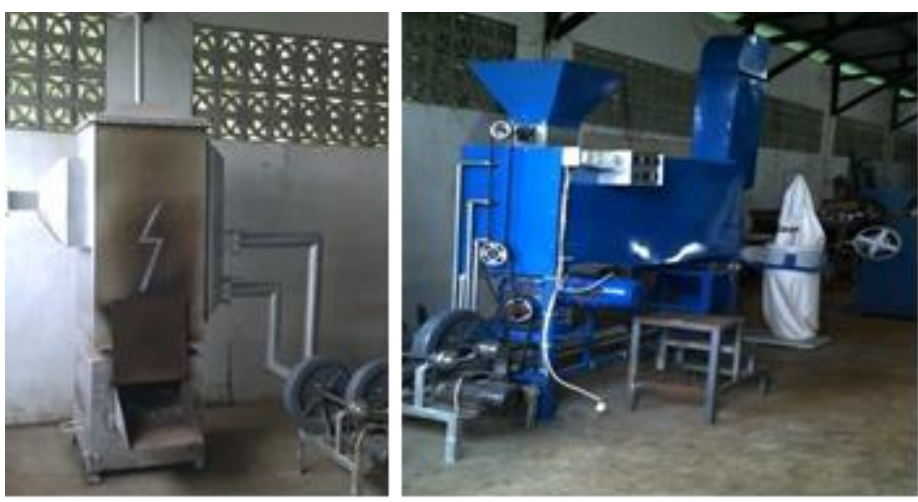

Gambar 2. Konstruksi pengering pati sagu agitated fluidized bed tipe piringan silinder bertingkat

Untuk mengetahui distribusi suhu pada alat pengering, maka dilakukan pengukuran suhu pada setiap silinder agitator dan ruang fluidisasi. Sedangkan kebutuhan energi dan nilai efisiensi pengering AFB tipe PSB dihitung menggunakan Persamaan 1 sampai 9.

$$
\begin{aligned}
& q_{b}=m_{b b} \cdot h_{b b} \\
& q_{L}=P . t \\
& q_{p s}=m_{p s} \cdot c_{p p s} \cdot\left(T_{p o}-T_{l i n g}\right) \\
& c_{p p s}=1,424 m_{c a r}+1,549 m_{p r o}+1,675 m_{\text {fat }}+0,837 m_{a s h}+4,187 M_{p}
\end{aligned}
$$




$$
\begin{gathered}
q_{a}=m_{a} \cdot C_{a}\left(T_{p o}-T_{\text {ling }}\right) \ldots \ldots . . . \\
q_{u a}=m_{w} \cdot H_{f g} \ldots \ldots \ldots \ldots \ldots \ldots \ldots \ldots \ldots \ldots \\
q_{u}=\rho_{u} V_{u} C_{u}\left(T_{u}-T_{p o}\right) \ldots \ldots \ldots \\
\eta_{p}=\frac{q_{p s}+q_{a}+q_{a u}}{q_{u}} \times 100 \% \\
\eta_{e p}=\frac{q_{p s}+q_{a}+q_{a u}}{q_{B}+q_{L}} \times 100 \%
\end{gathered}
$$

dimana, $\mathrm{q}_{\mathrm{B}}$ energi dari tungku biomassa $(\mathrm{kJ}), \mathrm{q}_{\mathrm{L}}$ energi listrik $(\mathrm{kJ}), \mathrm{q}_{\mathrm{ps}}$ energi untuk memanaskan pati sagu atau panas sensibel pati sagu $(\mathrm{kJ}), \mathrm{q}_{\mathrm{a}}$ energi untuk menaikan suhu air di dalam pati sagu atau panas sensibel air $(\mathrm{kJ})$, qua energi untuk menguapkan air dalam pati sagu $(\mathrm{kJ})$, qu energi yang diberikan udara untuk memanaskan pati sagu $(\mathrm{kJ})$, mb massa bahan bakar $(\mathrm{kg}), \mathrm{h}_{\mathrm{bb}}$ nilai kalor bahan bakar $(\mathrm{kJ} / \mathrm{kg})$, $\mathrm{P}$ daya motor listrik (Watt), $\mathrm{t}$ waktu pengoperasian alat pengering ( $\mathrm{s} /$ detik), $\mathrm{m}_{\mathrm{ps}}$ massa pati sagu basah $(\mathrm{kg}), \mathrm{C}_{\mathrm{pps}}$ panas jenis pati sagu $\left(\mathrm{kJ} / \mathrm{kg} \cdot{ }^{\circ} \mathrm{C}\right), \mathrm{T}_{\mathrm{u}}$ suhu udara pengering $\left({ }^{\circ} \mathrm{C}\right), \mathrm{T}_{\text {ling }}$ suhu lingkungan $\left({ }^{\circ} \mathrm{C}\right), \mathrm{T}_{\mathrm{po}}$ suhu akhir pati sagu $\left({ }^{\circ} \mathrm{C}\right), \mathrm{V}_{\mathrm{u}}$ banyaknya volume udara selama pengeringan $\left(\mathrm{m}^{3}\right), \mathrm{c}_{\mathrm{u}}$ Panas jenis udara $\left(\mathrm{kJ} / \mathrm{kg}^{\circ} \mathrm{C}\right), \quad c_{\mathrm{a}}$ Panas jenis air $\left(\mathrm{kJ} / \mathrm{kg}^{\circ} \mathrm{C}\right), \rho_{\mathrm{u}}$ massa jenis udara $\left(\mathrm{kg} / \mathrm{m}^{3}\right), \mathrm{m}_{\mathrm{w}}$ banyaknya uap air yang harus diuapkan sampai kadar air akhir $(\mathrm{kg}), \mathrm{m}_{\mathrm{a}}$ selisih massa awal pati sagu basah dengan massa kering $(\mathrm{kg}), \mathrm{h}_{\mathrm{fg}}$ entalphi air $(\mathrm{kJ} / \mathrm{kg}), \mathrm{M}_{\mathrm{psi}}$ kadar air awal pati sagu (\% bb), $\mathrm{M}_{\mathrm{pso}}$ kadar air akhir pati sagu (\% bb), $\eta_{\mathrm{p}}$ efisiensi panas atau pengeringan (\%), $\eta_{\text {ap }}$ efisiensi alat pengering (\%), $\mathrm{m}_{\mathrm{car}}$ kadar karbohidrat $(\%), \mathrm{m}_{\text {pro }}$ kadar protein $(\%), \mathrm{m}_{\text {fat }}$ kadar lemak (\%), $\mathrm{m}_{\text {ash }}$ kadar abu (\%).

Panas jenis atau panas spesifik (specific heat) untuk bahan yang diketahui komposisinya seperti pati (starch) dapat dihitung menggunakan persamaan empiris (Dickerson, 1969; dalam Singh dan Heldman, 2001). Sedangkan nilai kalor kayu yang digunakan adalah $18 \mathrm{MJ} / \mathrm{kg}$ (Manual Statistik Energi, 2005), dan nilai kalor tempurung kelapa 18,20 MJ/kg (Safrizal dkk., 2012).

Analisis data dilakukan dengan menggunakan persamaan matematis yaitu Persamaan 1 sampai 9. Data yang diperoleh dari hasil analisis tersebut, dinyatakan dalam bentuk grafik dan tabel, kemudian dibahas secara deskriptif.

\section{HASIL DAN PEMBAHASAN}

Sebaran suhu dalam silinder dan ruang fluidisasi menggunakan kayu bakar dapat dilihat pada Gambar 3. Distribusi suhu diantaranya pada silinder atas $54,82^{\circ} \mathrm{C}$, silinder tengah $53,55^{\circ} \mathrm{C}$, silinder bawah $50,64^{\circ} \mathrm{C}$, suhu ruang fluidisasi $66,64^{\circ} \mathrm{C}$ sedangkan suhu lingkungan $31,05^{\circ} \mathrm{C}$.

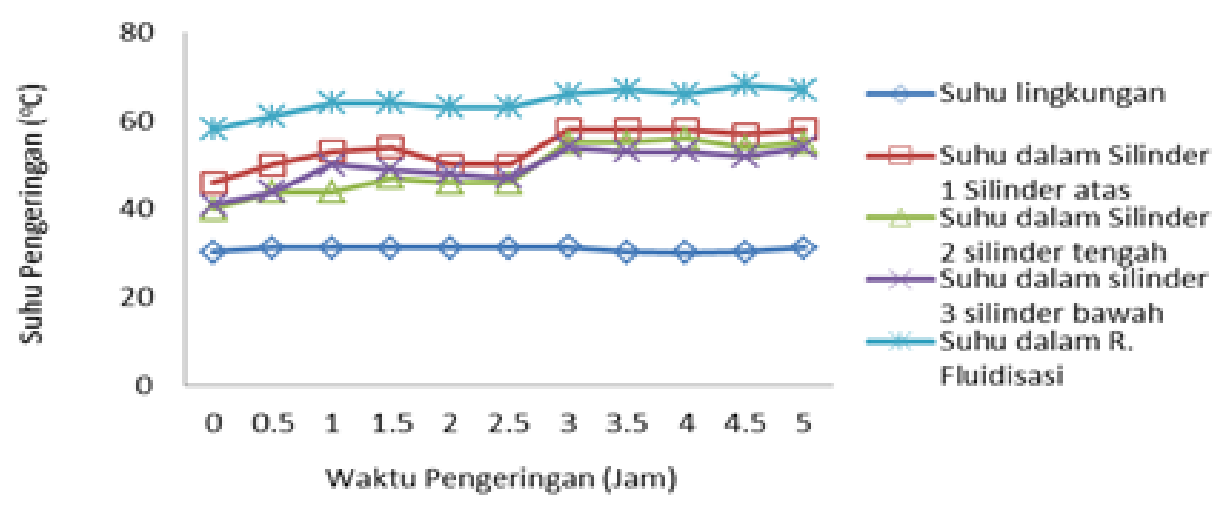

Gambar 3. Grafik suhu selama pengeringan dengan biomassa kayu bakar 
Berbeda dengan pengeringan menggunakan biomassa tempurung kelapa, diperoleh kisaran suhu $53,82{ }^{\circ} \mathrm{C}$ sampai $64,27{ }^{\circ} \mathrm{C}$. Silinder atas $53,82{ }^{\circ} \mathrm{C}$, silinder tengah $49,27{ }^{\circ} \mathrm{C}$, silinder bawah $49,55^{\circ} \mathrm{C}$ dan ruang fluidisasi $64,27^{\circ} \mathrm{C}$. Sebaran suhu pada pengering biomassa tempurung kelapa dapat dilihat pada Gambar 4.

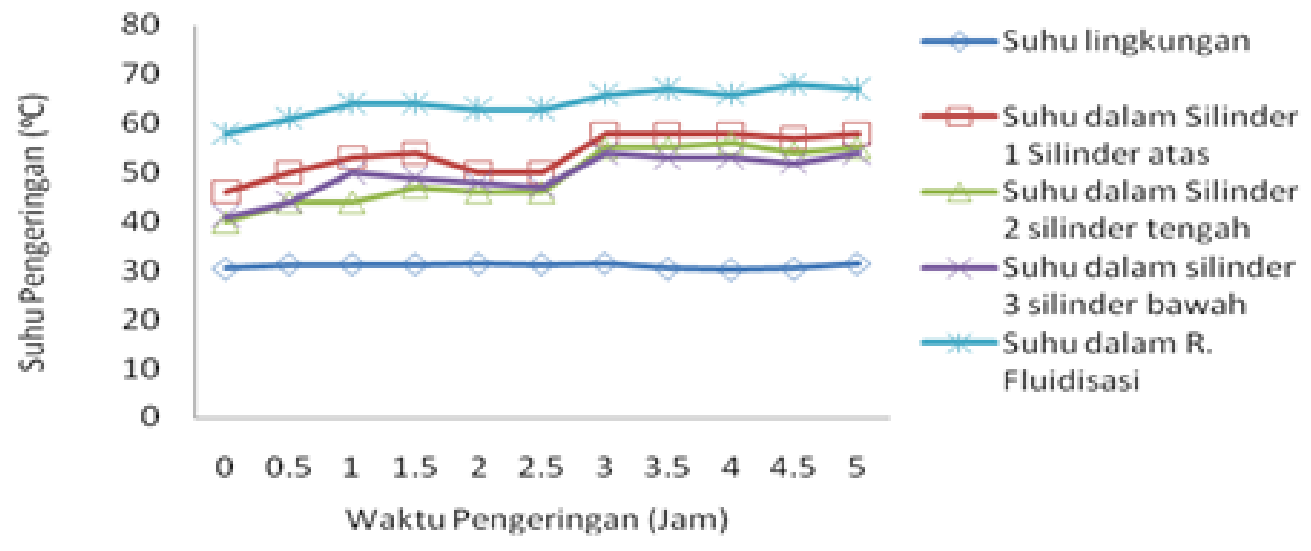

Gambar 4. Grafik suhu selama pengeringan dengan biomassa tempurung kelapa

Sebaran suhu di dalam silinder cukup merata, hal ini diduga karena silinder mengalami perputaran untuk proses penghancuran gumpalan-gumpalan pati, sehingga setiap silinder mendapatkan panas secara merata. Sebaran suhu pada ruang fluidisasi dari kedua biomassa diduga dipengaruhi oleh perbedaan akumulasi jumlah nilai kalor yang dimiliki oleh bahan penyusunnya pada masing-masing biomassa tersebut. Sebaran suhu di dalam ruang silinder dan ruang fluidisasi dapat dilihat pada Tabel 2 . Gambar 3 dan Gambar 4 menunjukkan ratarata perubahan suhu pengeringan yang ada dalam ruang agitator dan fluidisasi telah memenuhi suhu maksimum yang diijinkan untuk proses pengeringan pati sagu. Suhu pengeringan maksimum untuk pengeringan pati sagu adalah $70^{\circ} \mathrm{C}$. Hal ini perlu diperhatikan agar tidak terjadi gelatinisasi pati sagu selama proses pengeringan, karena suhu gelatinisasi pati sagu adalah $68-70^{\circ} \mathrm{C}$. Jika suhu dalam silinder melebihi suhu maksimum tersebut, maka akan terjadi proses gelatinisasi terhadap pati sagu. Gelatinisasi sangat dihindari dalam proses pengeringan pati sagu karena menyebabkan kegagalan dalam proses pembuatan pati.

Tabel 2. Perbandingan suhu pada alat pengering AFB tipe PSB menggunakan biomassa kayu bakar dan tempurung kelapa

\begin{tabular}{clcc}
\hline \multirow{2}{*}{ No } & \multicolumn{1}{c}{ Parameter } & Kayu bakar & Tiomassa \\
\cline { 3 - 4 } & & $31,05^{\circ} \mathrm{C}$ & $30,05^{\circ} \mathrm{C}$ \\
\hline 1 & Suhu luar & $54,82^{\circ} \mathrm{C}$ & $53,82^{\circ} \mathrm{C}$ \\
2 & Silinder 1 bagian atas & $53,55^{\circ} \mathrm{C}$ & $49,27^{\circ} \mathrm{C}$ \\
3 & Silinder 2 bagian tengah & $50,64^{\circ} \mathrm{C}$ & $49,55^{\circ} \mathrm{C}$ \\
4 & Silinder 3 bagian bawah & $66,64^{\circ} \mathrm{C}$ & $64,27^{\circ} \mathrm{C}$ \\
5 & Ruang fluidisasi &
\end{tabular}

Data pada Tabel 2 menunjukkan sebaran suhu di dalam ruang silinder dan fluidisasi pada dua perlakuan bahan bakar yang berbeda, dengan suhu luar $31,05^{\circ} \mathrm{C}$. Data pada tabel menunjukkan bahwa suhu yang dihasilkan kayu bakar lebih tinggi dari pada suhu tempurung kelapa. Hal ini diduga karena tingkat kelembaban dan kekeringan dari kedua bahan bakar tersebut. Dalam hal ini, kadar air awal masing-masing bahan bakar tidak diperhitungkan dalam penelitian ini.

Dari data tersebut menunjukkan bahwa semakin tinggi suhu, maka semakin cepat pula proses pengeringan berlangsung. Makin tinggi 
suhu udara pengering makin besar energi panas yang dibawa udara sehingga makin banyak jumlah massa cairan yang diuapkan dari permukaan bahan.

Namun demikian, pengeringan yang terlampau cepat dapat merusak bahan, oleh karena permukaan bahan cepat kering, sehingga kurang biasa diimbangi dengan kecepatan gerakan air menuju permukaan. Karenanya akan menyebabkan pengerasan pada permukaan bahan atau case hardening, sehingga air dalam bahan tidak dapat lagi menguap karena terhambat.

Laju penguapan air bahan pangan dalam pengeringan sangat ditentukan oleh kenaikan suhu. Semakin besar perbedaan antara suhu media pemanas dengan bahan yang dikeringkan, semakin besar pula kecepatan pindah panas ke dalam bahan pangan, sehingga penguapan air dari bahan akan lebih banyak dan cepat. Makin tinggi suhu dan kecepatan aliran udara pengering makin cepat pula proses pengeringan berlangsung. Makin tinggi suhu udara pengering makin besar energi panas yang dibawa udara sehingga makin banyak jumlah massa cairan yang diuapkan dari permukaan bahan yang dikeringkan. Jika kecepatan aliran udara pengering makin tinggi maka makin cepat pula massa uap panas yang dipindahkan dari bahan ke atmosfir (Taib dkk., 1998).

Bakker Arkema (1992) dalam Taufiq (2004) mengemukakan pengeringan bahan hasil pertanian menggunakan aliran udara pengering yang baik adalah antara $45^{\circ} \mathrm{C}$ sampai $75^{\circ} \mathrm{C}$. Pengering pada suhu dibawah $45^{\circ} \mathrm{C}$ mikroba dan jamur yang merusak produk masih hidup, sehingga daya awet dan mutu produk rendah namun pada suhu pengering diatas $75^{\circ} \mathrm{C}$ menyebabkan struktur kimiawi dan fisik produk, karena perpindahan panas dan massa air yang berdampak perubahan struktur sel (Setiyo, 2003).

Hasil analisis kinerja alat pengering AFB tipe PSB menggunakan biomassa kayu bakar dan tempurung kelapa yang terdiri dari kebutuhan energi, efisiensi panas dan efisiensi alat pengering dapat dilihat pada Tabel 3 . Massa bahan bakar antara kayu bakar dan tempurung kelapa berbeda, hal ini disebabkan pada proses pengumpanan bahan bakar ke dalam tungku bahan bakar sangat sulit dikendalikan.

Tabel 3. Perbandingan nilai efisiensi pengering menggunakan bahan bakar kayu bakar dan tempurung kelapa

\begin{tabular}{|c|c|c|c|}
\hline Variabel & Satuan & $\begin{array}{c}\text { Bahan } \\
\text { Bakar } \\
\text { Kayu } \\
\text { bakar }\end{array}$ & $\begin{array}{c}\text { Bahan } \\
\text { Bakar } \\
\text { Tempurung } \\
\text { Kelapa }\end{array}$ \\
\hline Massa bahan bakar & $\mathrm{Kg}$ & 67 & 70 \\
\hline Nilai Kalor (panas) bahan bakar & $\mathrm{kJ} / \mathrm{kg}$ & $16 \times 10^{3}$ & $18,2 \times 10^{3}$ \\
\hline Massa pati sagu & $\mathrm{Kg}$ & 30 & 30 \\
\hline Panas Jenis Pati Sagu $\left(\mathbf{C}_{\mathbf{p p s}}\right)$ & $\mathrm{kJ} / \mathrm{kg}$ & 1,22 & 1,22 \\
\hline Lama pengeringan & Jam & 5 & 5 \\
\hline Energi Pembakaran tungku (qB) & $\mathrm{kJ}$ & $1072 \times 10^{3}$ & $1274 \times 10^{3}$ \\
\hline Energi Listrik yang digunakan $(\mathbf{q L})$ & $\mathrm{kJ}$ & $55,98 \times 10^{3}$ & $55,98 \times 10^{3}$ \\
\hline Energi untuk memanaskan pati sagu (q $\mathbf{q}_{\mathrm{ps})}$ & $\mathrm{kJ}$ & 415 & 390 \\
\hline Energi untuk menaikkan suhu air dalam pati sagu $\left(\mathbf{q}_{\mathbf{a}}\right)$ & $\mathrm{kJ}$ & 1037 & 973 \\
\hline Energi untuk menguapkan air dalam pati sagu (qua) & $\mathrm{kJ}$ & $26,784 \times 10^{3}$ & $26,631 \times 10^{3}$ \\
\hline Energi yang diberikan udara untuk memanaskan pati sagu $\left(\mathbf{q}_{\mathbf{u}}\right)$ & $\mathrm{kJ}$ & $74,119 \times 10^{3}$ & $74,119 \times 10^{3}$ \\
\hline Efisiensi pemanasan/pengeringan $\left(\eta_{p}\right)$ & $\%$ & 38,09 & 37,76 \\
\hline Efisiensi Alat Pengering $\left(\eta_{\text {ap }}\right)$ & $\%$ & 2,50 & 2,10 \\
\hline
\end{tabular}

Energi yang dihasilkan oleh tungku adalah energi panas melalui proses pembakaran biomassa (kayu bakar dan tempurung kelapa) dalam ruang bakar, yang dialirkan ke ruang pemindah panas secara alami kemudian dihisap oleh blower ke dalam ruang pengering (silinder agitator dan fluidisasi).

Besarnya nilai energi tersebut dipengaruhi oleh nilai kalor dan banyaknya 
bahan bakar yang digunakan. Energi pembakaran yang dihasilkan tungku $\left(\mathrm{q}_{\mathrm{B}}\right)$ dari masing-masing bahan bakar biomassa dihitung menggunakan Persamaan 1. Hasil perhitungan dapat dilihat dalam Tabel 3.

Data pada Tabel 3 menunjukkan adanya perbedaan nilai kalor dan bobot (massa) antara kedua bahan bakar biomassa. Nilai kalor kayu bakar $16 \times 10^{3} \mathrm{~kJ} / \mathrm{kg}$, sedangkan tempurung kelapa $18,2 \times 10^{3} \mathrm{~kJ}$, hal ini dipengaruhi oleh adanya komponen penyusun kimia dalam bahan bakar itu sendiri (Tillman, 1976). Menurut Prawirohatmodjo (2004), pengaruh susunan kimia berasal dari lignin yang memiliki nilai kalor lebih tinggi $( \pm 6.100$ $\mathrm{kkal} / \mathrm{kg}$ ) dibandingkan dengan selulosa (4.150 $-4.350 \mathrm{kkal} / \mathrm{kg}$ ).

Besarnya nilai energi listrik $\left(\mathrm{q}_{\mathrm{L}}\right)$ yang digunakan selama proses pengeringan dihitung berdasarkan daya motor listrik $(3,11 \mathrm{~kW})$ dan waktu pengoperasian alat pengering (5 jam atau $18.000 \mathrm{~s}$ ) menggunakan Persamaan 2. Hasil perhitungan tersebut dapat dilihat pada Tabel 3, yaitu sebesar 55,98 x $10^{3} \mathrm{~kJ}$.

Data pada Tabel 3 menunjukkan energi listrik yang dibutuhkan pada pengeringan menggunakan kayu bakar dengan tempurung kelapa adalah sama, hal ini disebabkan pada pengujian tersebut menggunakan alat pengering yang sama yaitu daya motor listrik penggerak blower $(0,75 \mathrm{~kW})$ dengan agitator $(2,36 \mathrm{~kW})$.

Efisiensi pemanasan atau pengeringan $\left(\eta_{\mathrm{p}}\right)$ adalah perbandingan energi yang dimanfaatkan $\left(\mathrm{q}_{\mathrm{ps}}+\mathrm{q}_{\mathrm{a}}+\mathrm{q}_{\mathrm{ua}}\right)$ dengan energi yang diberikan oleh udara pengering $\left(\mathrm{q}_{\mathrm{u}}\right)$. Efisiensi pemanasan dihitung berdasarkan persamaan 7 . Dari hasil perhitungan diperoleh nilai efisiensi sebesar 38,09\% untuk kayu bakar dan 37,76\% untuk tempurung kelapa, ini berarti bahwa efisiensi pengeringan untuk kedua sampel hampir sama.

Efisiensi pemanasan dipengaruhi oleh besarnya energi untuk memanaskan pati sagu $\left(\mathrm{q}_{\mathrm{ps}}\right)$ yang dapat dihitung menggunakan Persamaan 3, energi untuk menaikkan suhu air dalam pati sagu $\left(\mathrm{q}_{\mathrm{a}}\right)$ Persamaan 4 , energi untuk menguapkan air dalam pati sagu (qua) Persamaan 5, dan energi yang diberikan udara untuk memanaskan pati sagu $\left(\mathrm{q}_{\mathrm{u}}\right)$ Persamaan 6 . Nilai $\mathrm{q}_{\mathrm{ps}}, \mathrm{q}_{\mathrm{a}}, \mathrm{q}_{\mathrm{ua}}$ dan $\mathrm{q}_{\mathrm{u}}$ pada masing-masing biomassa dapat dilihat dalam Tabel 3 .

Hasil analisis menunjukkan adanya perbedaan nilai energi yang dimanfaatkan pada masing-masing biomassa, hal ini disebabkan perubahan suhu dan kadar air akhir pati sagu yang berbeda selama proses pengeringan. Dengan adanya perbedaan tersebut maka akan berpengaruh juga terhadap nilai efisiensi pada masing-masing biomassa. Efisiensi panas yang dihasilkan dari penelitian ini berbeda dengan hasil penelitian Taufiq (2004) yang menyampaikan bahwa efisiensi panas pada alat pengering fluidized bed adalah sebesar 23,6\% pada suhu $60^{\circ} \mathrm{C}$.

Efisiensi alat pengering $\left(\eta \mathrm{a}_{\mathrm{p}}\right)$ adalah perbandingan energi yang dimanfaatkan $\left(\mathrm{q}_{\mathrm{ps}}+\mathrm{q}_{\mathrm{a}}+\mathrm{q}_{\mathrm{ua}}\right)$ dengan energi yang diberikan alat pengering $\left(\mathrm{q}_{\mathrm{B}}+\mathrm{q}_{\mathrm{L}}\right)$. Nilai efisiensi alat pengering AFB tipe PSB dari masing-masing biomassa dapat dihitung menggunakan Persamaan 8. Hasil perhitungan nilai efisiensi adalah 2,50\% untuk kayu bakar dan 2,10\% untuk tempurung kelapa, seperti dalam Tabel 3, dengan demikian efisiensi alat pengering pada masing-masing biomassa hampir sama. Nilai efisiensi tersebut lebih rendah dari nilai efisiensi alat pengering jagung yang dikembangkan oleh Taufiq (2004) yaitu 3,4\%. Nilai efisiensi alat pengering dalam Tabel 3 juga lebih rendah dibandingkan dengan efisiensi pengeringan. Menurut Taufiq (2004), ini dikarenakan analisis efisiensi alat pengering meliputi keseluruhan sistem sedangkan untuk efisiensi pengeringan hanya menyangkut sistem dalam ruang pengering.

Selain itu rendahnya efisiensi pemanasan dan alat pengering disebabkan oleh kurang efektifnya tungku biomassa, kehilangan panas pada saluran udara pengering ke dalam ruang agitator, dan kapasitas ruang agitator yang masih rendah. Menurut Soponronnarit dkk. (2000) untuk mendapatkan pengoperasian yang optimum maka diperlukan konsumsi energi yang lebih rendah dengan waktu pengeringan yang lebih singkat.

Pada penelitian ini menunjukkan waktu pengeringan agak lambat (lebih lama) hal ini disebabkan tingkat kepadatan dan daya lengket pati sagu yang tinggi sehingga mempengaruhi kinerja silinder. Silinder tidak dapat memisahkan gumpalan pati sagu secara sempurna sehingga menghasilkan butiranbutiran pati sagu.

Selain itu, butiran-butiran tersebut menghambat proses perpindahan panas ke dalam bahan. Menurut Wetchacama dkk. (2000) selain suhu, kadar air selama pengeringan juga sangat dipengaruhi oleh proses pengadukan sehingga distribusi suhu 
merata pada setiap permukaan pati, dan menghindari gumpalan-gumpalan (bongkahan) pati.

Penurunan kadar air bahan selama proses pengeringan dipengaruhi oleh besarnya suhu dan waktu pengeringan, semakin bertambahnya waktu pengeringan akan mengakibatkan terjadinya penurunan kadar air bahan. Dengan menurunnya kandungan air bahan mengakibatkan efisiensi pengeringan juga akan menurun, hal ini dapat dijelaskan bahwa proses pengeringan akan mengakibatkan kandungan uap air suatu bahan akan menguap sehingga kadar air bahan makin lama makin berkurang.

Berkurangnya kandungan air bahan maka energi panas yang diperlukan atau dimanfaatkan oleh bahan akan kecil, dan banyak energi panas hasil pembakaran yang terbuang sedangkan dengan semakin kecilnya energi panas yang dipergunakan untuk pengeringan maka efisiensi pengeringan juga akan mengecil. Perubahan kadar air sagu dihitung berdasarkan persentase bobot basah (wet basis) dapat dilihat pada Tabel 4.

Tabel 4. Kadar air akhir pati sagu

\begin{tabular}{lcccc}
\hline Variabel & Satuan & $\begin{array}{c}\text { Bahan Bakar } \\
\text { Kayu Bakar }\end{array}$ & $\begin{array}{c}\text { BahanBakar } \\
\text { Tempurung } \\
\text { Kelapa }\end{array}$ & SNI 3729-2008 \\
\hline Massa pati sagu & $\mathrm{Kg}$ & 30 & 30 & - \\
Suhu pengeringan & ${ }^{\circ} \mathrm{C}$ & 66,64 & 66,27 & - \\
Lama pengeringan & $\mathrm{Jam}$ & 5 & 5 & - \\
Kadar air awal pati sagu & $\% \mathrm{bb}$ & 42 & 42 & Maks. 13,00 \\
Kadar air akhir pati sagu & $\% \mathrm{bb}$ & 12,02 & 12,21 & \\
\hline
\end{tabular}

Prinsip penetapan kadar air dengan metode pemanasan biasa (gravimetri) adalah menguapkan air yang terkandung dalam bahan dengan jalan pemanasan. Bahan tersebut dipanaskan sampai memiliki berat yang konstan. Berat yang konstan menunjukkan bahwa kandungan air pada bahan telah menguap seluruhnya, dan hanya tersisa berat kering bahan itu sendiri.

Tabel 4 memperlihatkan perbedaan kandungan air akhir pati sagu yang diperlakukan dengan perbedaan suhu pengeringan. Kadar air akhir pati sagu dengan bahan bakar kayu bakar adalah12,21\% diperoleh dari pengeringan dengan suhu $66,27^{\circ} \mathrm{C}$, sedangkan kadar air akhir pati sagu dengan bahan bakar tempurung kelapa suhu adalah12,02\%dengan suhu pengeringan $66,64^{\circ} \mathrm{C}$. Waktu pengeringan dari kedua perlakuan tersebut adalah selama 5 jam.. Persyaratan kadar air maksimum untuk pati sagu kering adalah $13 \%$ menurut Standar Nasional Indonesia 3729-2008, dengan demikian kadar air tertinggi yang dihasilkan pada penelitian ini telah memenuhi syarat mutu karena tidak melebihi nilai syarat yang ditetapkan.

Tabel 4 juga menunjukkan bahwa terdapat selisih penurunan kadar air pati sagu $0,19 \% \mathrm{bb}$, hal ini sangat dipengaruhi oleh besarnya suhu pengeringan. Semakin tinggi suhu pengeringan, maka proses penurunan kadar air akan semakin cepat, dan lebih mempercepat proses pengeringan. Menurut Adi dkk. (2013) semakin tinggi suhu pengeringan akan diperoleh kadar air semakin rendah.

Air merupakan komponen penting dalam makanan, karena air dapat membuat suatu bahan pangan menjadi baik atau buruk. Keberadaan air dalam bahan pangan akan mempengaruhi bahan pangan tersebut dalam beberapa hal, diantaranya penampakan, penerimaan (acceptability), daya simpan, dan lain-lain.

\section{KESIMPULAN}

Distribusi suhu yang terjadi di dalam ruang agitator merata dengan baik. Pengering Agitated Fluidized Bed tipe Piringan Silinder Bertingkat memiliki kapasitas $30 \mathrm{~kg} / 5$ jam. Efisiensi pengeringan dan alat pengering untuk kayu bakar adalah 38,09\% dan 2,5\%, sedangkan untuk tempurung kelapa $37,76 \%$ dan $2,1 \%$, dengan konsumsi energi biomassa kayu bakar $1072 \times 10^{3} \mathrm{~kJ}$, tempurung kelapa1274 x10 $\mathrm{kJ}$, energi listrik $55,98 \times 10^{3}$ $\mathrm{kJ}$. Suhu pengeringan dalam ruang agitator $\left(50,64^{\circ} \mathrm{C}-54,82^{\circ} \mathrm{C}\right)$ dan fluidisasi $\left(66,64^{\circ} \mathrm{C}\right)$ untuk kayu bakar, sedangkan untuk tempurung kelapa suhu dalam ruang agitator $\left(49,55^{\circ} \mathrm{C}\right.$ - 
$\left.53,82^{\circ} \mathrm{C}\right)$ dan ruang fluidisasi $\left(64,27^{\circ} \mathrm{C}\right)$.Pengering AFB tipe PSB mampu menurunkan kadar air pati sagu dari $42 \%$ basis basah menjadi $12,02 \%$ untuk bahan bahan bakar kayu, dan 12,21\% untuk bahan bakar tempurung kelapa.

\section{UCAPAN TERIMA KASIH}

Peneliti mengucapkan terima kasih kepada Kementerian Riset dan Teknologi Direktorat Jenderal Pendidikan Tinggi, atas dana yang diberikan melalui Hibah Penelitian Strategis Nasional tahun 2017, dengan nomor kontrak 059/SP2H/DRPM/II/2016.

\section{DAFTAR PUSTAKA}

Adi, R., Amalia, N., and Ratnawari. (2013). Penggunaan Teknologi Pengeringan Unggun Terfluidisasi untuk Meningkatkan Efisiensi Pengeringan Tepung Tapioka, Jurnal Teknologi Kimia dan Industri. 2(3), pp. 37-42.

AOAC, (2005). Official Method of Analysis of The Assosiation of Official Analytical Chemist. Association of Official Analytical Chemist, Inc. Arlington, Virginia, USA.

Badan Standardisasi Nasional Indonesia. (2008). Tepung Sagu. Standar Nasional Indonesia. SNI 3729: 2008.

Bintoro, M.H., 2019, Potensi dan Produksi Sagu di Indonesia. https://faperta.ipb.ac.id/buletin/2019/0 4/12/potensi-dan-produksi-sagu-diindonesia/

Chung, D.S., and D.I., Chang. (1982), Principles of Food Dehydration, Journal. Food Protec. 45(5), pp. 475478.

Dirjen Perkebunan Kementerian Pertanian. (2013). Peningkatan Produksi, Produktivitas dan Mutu Tanaman Tahunan. Pedoman Teknis Pengembangan Tanaman Sagu Tahun 2013.

Flach, M. 1983. The Sago Palm. FAO Plant Production and Protection. FAO of The United Nasional. Rome. 85 pp.

Haryanto, B. dan P. Pangloli. 1992. Potensi dan Pemanfaatan Sagu. Kanisius. Yogyakarta

Heldman, D.R., and Lund, D.B., (1992).
Handbook of Food Engineering. Marcel Dekker, Inc. New York, Basel, Hongkong.

Jading, A., Aman, W.P., Fangohoy, B., Payung, P., and Tethool, E.F., (2015), Kinerja Pengering PAti Sagu Model Agitated Fluidized Bed Bertenaga Listrik dan Biomassa. Prosiding Seminar Nasional PERTETA 2015 Peran PERTETA dalam Mendukung Swassembada Pangan Nasional 2017. Makassar, Indonesia, 5-7 Agustus 2015, pp. 1-5.

Jading, A., Payung, P., and Tethool, E.F., (2019), Evaluasi Kinerja dan Konsumsi Energi Pengering Pati Sagu Model Agitated Fluidized Bed Bertenaga Biomassa, Agritechnology, 2(2), pp. 53-62.

Jong, F.S., and Widjono, A., (2007), Sagu: Potensi Besar Pertanian Indonesia. Jurnal Iptek Tanaman Pangan 2(1), pp. 54-65.

Khatir, R., Ratna, and Wardani, (2011), Karakteristik Pengeringan Tepung Beras Menggunakan Alat Pengering Tipe Rak. Jurnal Ilmiah Pendidikan Biologi 3(2), pp. 1-4.

Kurniawan, A., Darma., and Istalaksana, P., (2012), Pengembangan Agroindustri Pengolahan Sagu Di Provinsi Papua Untuk Mendukung Ketahanan dan Diversifikasi Pangan. Prosiding Insinas, Jakarta, 29-30 November 2012.

Manual Statistik Energi. (2005), International Energy Agency., IEA publications, 9 rue de la Fédération, 75739 PARIS Cedex 15.

Marsetio, (2009), Pelatihan Teknologi Pengolahan Hasil Pertanian Pengeringan dan Penyimpanan Bijibijian. IPB. Bogor. Indonesia.

Prawirohatmodjo, S., (2004), Sifat-sifat Fisika Kayu. Bagian Penerbitan Fakultas Kehutanan UGM. Yogyakarta. Indonesia

Ruddle, K., Johnson, D., Townsend, P.K. and Ress. J.D., (1978), Palm Sago A Tropical Starch From Marginal Lands. An. East-West Centre Book. Honolulu.

Safrizal, R., Syah, H., and Khatir, R., (2012), Analisis Efisiensi pada Sistem Pengeringan Bunga Rosella (Hibiscus sabdariffa L) Menggunakan Alat 
Pengering Tipe Lemari. Jurnal Rona Teknik Pertanian 5(2), pp. 364-367.

Setiyo, Y., (2003), Aplikasi Sistem Kontrol Suhu dan Pola Aliran Udara pada Alat Pengering Tipe Kotak untuk Pengeringan Buah Salak, Pengantar Falsafat Sains. Program Pasca Sarjana, IPB. Indonesia.

Singh, R.P., and Helman, D.R., (2009), Introduction to Food Engineering. Fourth Edition. Academic Press, London.

Soponronnarit, S., Wetchama, S., Trutassanawin, S., and Jariyatontivait., W., (2000), Design, Testing, and Optimization of Vibro-Fluidized Bed Paddy Dryer.Proceeding of The $12^{\text {th }}$ International Drying Symposium IDS2000, August 28-31, Noodwijkerhout, Netherlands.
Taufiq, M., (2004), Pengaruh Temperatur Terhadap Laju Pengeringan Jagung Pada Pengering Konvensional dan Fluidized Bed. Skripsi, Fakultas Teknik, Universitas Sebelas Maret, Surakarta.

Tillman, D. A., (1976), Wood As an Energy Resource. Academic Press. New York.

Wetchacama, S., Soponronnarit, S., and Jariyatontivait, W., (2000), Development of a Commercial Scale Vibro-Fluidized Bed Paddy Dryer. Journal Natural Science 34, pp. 423430. 